\title{
Assessment of trace metal air pollution in Paris using slurry-TXRF analysis on cemetery mosses
}

\author{
Marco Natali ${ }^{1}$ Augusto Zanella ${ }^{2} \cdot$ Aleksandar Rankovic $^{3,4} \cdot$ Damien Banas $^{5}$. \\ Chiara Cantaluppi $^{1} \cdot$ Luc Abbadie $^{3} \cdot$ Jean -Christophe Lata ${ }^{3,6}$
}

Received: 21 April 2016 / Accepted: 8 August 2016/Published online: 10 September 2016

(C) Springer-Verlag Berlin Heidelberg 2016

\begin{abstract}
Mosses are useful, ubiquitous accumulation biomonitors and as such can be used for biomonitoring surveys. However, the biomonitoring of atmospheric pollution can be compromised in urban contexts if the targeted biomonitors are regularly disturbed, irregularly distributed, or are difficult to access. Here, we test the hypothesis that cemeteries are appropriate moss sampling sites for the evaluation of air pollution in urban areas. We sampled mosses growing on gravestones in 21 urban and periurban cemeteries in the Paris metropolitan area. We focused on Grimmia pulvinata (Hedwig) Smith, a species abundantly found in all studied cemeteries and very common in Europe. The concentration of $\mathrm{Al}, \mathrm{As}, \mathrm{Br}, \mathrm{Ca}, \mathrm{Ce}$, $\mathrm{Cl}, \mathrm{Cr}, \mathrm{Cu}, \mathrm{Fe}, \mathrm{K}, \mathrm{Mn}, \mathrm{Ni}, \mathrm{V}, \mathrm{P}, \mathrm{Pb}, \mathrm{Rb}, \mathrm{S}, \mathrm{Sr}, \mathrm{Ti}$, and $\mathrm{Zn}$ was determined by a total reflection X-ray fluorescence
\end{abstract}

Responsible editor: Philippe Garrigues

Highlights - Cemetery mosses were used as biomonitors of trace metal air pollution in Paris region.

- Slurry-TXRF method might be successfully used with moss material.

- Polluted cemeteries are in traffic congested areas, under main winds influence.

- Green cemeteries are less polluted than smaller cemeteries with low tree density.

- Cemetery moss sampling could be a useful complement for monitoring urban areas.

Augusto Zanella

augusto.zanella@unipd.it

1 Institute of Condensed Matter Chemistry and Technologies for Energy, ICMATE-CNR, 35127 Padova, Italy

2 University of Padua, Agripolis, Department TESAF, Viale dell'Università, 16, Legnaro, 35020 Padova, Italy

3 Sorbonne Universités, UPMC Univ Paris 06, CNRS, INRA, IRD, Univ Paris Diderot Paris 07, UPEC, UMR 7618, Institute of Ecology technique coupled with a slurry sampling method (slurryTXRF). This method avoids a digestion step, reduces the risk of sample contamination, and works even at low sample quantities. Elemental markers of road traffic indicated that the highest polluted cemeteries were located near the highly frequented Parisian ring road and under the influence of prevailing winds. The sites with the lowest pollution were found not only in the peri-urban cemeteries, adjoining forest or farming landscapes, but also in the large and relatively wooded cemeteries located in the center of Paris. Our results suggest that (1) slurry-TXRF might be successfully used with moss material, (2) G. pulvinata might be a good biomonitor of trace metals air pollution in urban context, and (3) cemetery moss sampling could be a useful complement for monitoring urban areas. and Environmental Sciences - Paris, Tour 44-45, 4 place Jussieu, 75005 Paris, France

4 Institute for Sustainable Development and International Relations, Sciences Po, 27 rue Saint Guillaume, F-75007 Paris, France

5 UR AFPA - INRA, Université de Lorraine, Boulevard des Aiguillettes, Vandoeuvre-Lès-Nancy, France

6 Department of Geoecology and Geochemistry, Institute of Natural Resources, Tomsk Polytechnic University, Lenin Avenue, 30, 634050 Tomsk, Russia 
Keywords Tracemetals $\cdot$ Air pollution $\cdot$ Biological indicator . Cemeteries · Grimmia pulvinata $\cdot$ Total reflection X-ray

fluorescence $\cdot$ Urban areas

\section{Introduction}

The monitoring of global atmospheric pollution in urban and peri-urban areas is at a crucial phase where the expectations of society in terms of environmental issues often exceed the capacity of integrative measures to track pollutants in the longterm. One way to meet this demand is the use of biomonitoring. It can be seen as an alternative to more conventional measurements of pollutants from air or precipitation, through cheaper, easier, and space- and time-integrated analyses (Chakrabortty and Paratkar 2006). However, monitoring using living organisms in a patchwork of urban and periurban areas that can rapidly evolve and are subject to strong anthropogenic pressure faces three major problems: (i) the need to have spatially integrative and regularly distributed sites with organisms that can serve as biomonitors but also are not subject to excessive disturbances, e.g., regular weeding; (ii) the need to have a biomonitor that is sufficiently ubiquitous, easily harvestable (including during all seasons) and recognizable, capable of accumulating pollutants and resistant; and (iii) selection of a technique that allows fast, simple, inexpensive, and precise quantification of pollutants that is adapted to the selected biomonitor.

For the selection of a suitable site, cemeteries in urban contexts may represent relatively protected areas compared to surrounding urban areas including parks. These sites are usually easy to access and regularly distributed, and the biomonitors may remain undisturbed during long periods. This may, however, depend on the history and management of the city, the spectrum of cemeteries histories, and their structural and spatial characteristics at local (e.g., proximity to urban road infrastructure) and regional (e.g., climate patterns interacting with built environment) scales.

For the selection of a suitable urban biomonitor, the use of mosses as biomonitors for air pollution has emerged for some time but is presently a matter of scientific debate. Few years ago, Aboal et al. (2010) stated that atmospheric deposition of metals cannot be accurately estimated from the concentrations in moss tissue. In fact, the heterogeneity of sources of elements (atmospheric deposition from natural sources, edaphic, and plant inputs), environmental conditions, and biological processes in mosses can interfere, rendering difficult the estimation of atmospheric deposition. However, over the past few decades, a large number of researchers have recognized mosses as valid biomonitors in order to assess whether nitrogen $(\mathrm{N})$ bioaccumulated in mosses reflects different land uses (Pesch et al. 2008; Boltersdorf et al. 2014), or for estimating the spatial distribution of atmospheric nitrogen deposition in Europe
(Harmens et al. 2011), or atmospheric derived sulfur (Liu et al. 2009) when mosses on open rocks are sampled. In a recent review, Harmens et al. (2013) stated that mosses are suitable organisms to monitor deposition of POPs, including polycyclic aromatic hydrocarbons (PAHs), polychlorobiphenyls (PCBs), dioxins and furans $(\mathrm{PCDD} / \mathrm{Fs})$, and polybrominated diphenyl ethers (PBDEs). Heavy metal pollution has also largely been investigated using mosses as biomonitors (e.g., Shacklette 1965; Rühling and Tyler 1970; Grodzinska 1978; Shaw 1989; Zechmeister 1994; Carpi et al. 1994; Poikolainen et al. 2004; Schintu et al. 2005; Giordano et al. 2005; Pesh and Schröder 2006; Holy et al. 2009; Viet et al. 2010; Ares et al. 2012; Correa Mazzoni et al. 2012; Giordano et al. 2013; Gerdol et al. 2014; Cowden et al. 2015; Harmens et al. 2015; Maxhuni et al. 2016). Indeed, these small, resistant, and relatively ubiquitous plants may well play an important biomonitoring role in future, crowded urban areas. Different protocols for active biomonitoring have been recently proposed (Ares et al. 2012; Harmens et al. 2014), and the replacement of naturally growing mosses with cultivated clones or with a commercial fleece has even been suggested (Giordano et al. 2013).

Mosses have several important advantages over other more conventional techniques. First, mosses are fixed to their substrate without real root system; additionally, they also exhibit a large surface-volume ratio that promotes migration of trace metals and other elements to the free cation-exchange sites located on the cell walls and the external side of cell membrane (Chopra and Kumra 1988; Steinnes 1995; Sucharova and Suchara 2004; Chakrabortty and Paratkar 2006). Metals are thus present in mosses at higher concentrations when compared with those in rainfall or air samples (Tyler 1970; Chopra and Kumra 1988; Rühling et al. 1989). Second, unlike stormwater analysis that allows assessing air pollution at a given time, mosses are perennial (annual growth succeeds the precedent on a single stem), are frequent and widespread, can integrate contamination over time, and are representative of sampling site's contamination. Third, thanks to their small size and the fact that they are living in relative independence from the substrate, mosses are generally easy to sample. These properties, combined with their ability to accumulate particles on the leaf surface and to exchange ions, are considered by many authors to make mosses good indicators of spatial trends and patterns of air contamination by trace metals on a regional scale (Steinnes et al. 1997; Zechmeister et al. 2003; Sutton et al. 2004; Cowden et al. 2015). Epilithic lichens also provide an excellent means to monitor atmospheric deposition over large areas in a fast, simple, cost-effective way (Matschullat et al. 1999), but they are often less uniformly distributed in urban sites and in particular in cemeteries.

For the selection of a suitable technique, a large range of methods have been used for measuring the heavy metal content in mosses (Harmens et al. 2008): inductively coupled plasma mass spectrometry (ICP-MS), flame atomic 
absorption spectroscopy (F-AAS), inductively coupled plasma emission spectroscopy (ICP-ES), graphite furnace atomic absorption spectroscopy (GF-AAS), instrumental neutron activation analysis (INAA), cold vapor atomic absorption spectrometry (CV-AAS), and advanced mercury analyzer (AMA). Klockenkaemper (1997) showed that total X-ray fluorescence spectroscopy (TXRF) is a reliable and convenient method for the determination of trace metal concentrations as it can be applied either with or without preliminary sample digestion. A review on biological and environmental TXRF applications has recently been published (De La Calle et al. 2013). TXRF with preliminary sample digestion (i.e., mineralization) has been used in biomonitoring to determine metal concentrations in algae (Sabatini et al. 2009; Varga et al. 1999; Barkàcs et al. 1999), waterweed (Woelfl et al. 2006), lichen (Montero et al. 2009; Borgese et al. 2009), and mosses (Markert et al. 1994; Zarazúa-Ortega et al. 2013). TXRF with "no or minimal treatment" and direct analysis on powdered samples was used on atmospheric dust collected on TXRF quartz carriers used as impaction plates (Injuk and Van Grieken 1995; Schmeling and Klockow 1997; Esaka et al. 2003; Schneider 1989), collected on filters (Borgese et al. 2012) or on adhesives (Cantaluppi et al. 2013). Finally, slurry sampling for TXRF was applied for biological samples (Meyer et al. 2012; De La Calle et al. 2012; Wellenreuther et al. 2008), drug substances (Shaw et al. 2012; Borgese et al. 2010), soils (Marguí et al. 2010), rocks (Marks et al. 2012), and archeological samples (Bonizzoni et al. 2013). Overall, "slurry sampling" appears to be the third most commonly used sample preparation method for TXRF, preceded by digestion and no (or minimal) treatment methods. Slurry sample preparation can be an especially convenient alternative to digestion, as skipping the sample digestion step, the risk of sample contamination, and element loss is reduced. This also allows avoiding lengthy digestion and vessel cleaning procedures.

In the present work, we (i) sought to assess the relevance of urban cemeteries for surveying the spatial variability of metal deposition, in the context of preliminary studies or as part of a larger program (e.g., atmospheric quality monitoring networks). We took the example of cemeteries located in the Paris Region (located within Paris and in the surrounding suburban zone), which can be considered as an example of a large European urban area; (ii) have targeted mosses present in these cemeteries as possible urban biomonitor candidates. This led us to consider Grimmia pulvinata (Hedwig) Smith as study species; (iii) chose to analyze the metal accumulation in mosses with a TXRF slurry sampling method (slurryTXRF), a cost-effective method in terms of consumable use and preparation time. We analyzed the concentration of the following 20 elements- $\mathrm{Al}, \mathrm{As}, \mathrm{Br}, \mathrm{Ca}, \mathrm{Ce}, \mathrm{Cl}, \mathrm{Cr}, \mathrm{Cu}, \mathrm{Fe}$, $\mathrm{K}, \mathrm{Mn}, \mathrm{Ni}, \mathrm{V}, \mathrm{P}, \mathrm{Pb}, \mathrm{Rb}, \mathrm{S}, \mathrm{Sr}, \mathrm{Ti}$, and $\mathrm{Zn}$ - and calculated background enrichment factors to better separate the elements according to their anthropic or natural origins. While not exhaustive of all metal pollutants that can be found in urban areas, this list of elements was sufficient to identify variations of a potential air pollution across the Paris area. As the application of the slurry-TXRF method on mosses was done here for the first time, we also compared it for validation with the digestion-TXRF method that has been previously used successfully for moss analysis.

\section{Materials and methods}

\section{Studied sites}

The chosen sampling sites were urban cemeteries located within Paris and out of the city in the surrounding suburban zone. On the whole, the study was carried out on 17 Paris and 4 suburban cemeteries (20-80 km from the center of Paris). All central Paris cemeteries were sampled except a small cemetery in Montmartre, privately owned and accessible only 1 day/year. Central Paris cemeteries (Fig. 1-right panel) are distributed over the entire city area contained within the ring road and with a large variety of characteristics such as size, vegetation cover, and proximity to the ring road. As an intermediate suburban zone, we selected the cemeteries in the City of Versailles (Fig. 1-right panel), $20 \mathrm{~km}$ west from Paris. Finally, a cemetery considered as less polluted and having most natural background control reference was chosen in Nemours (Fig. 1-left panel), a site located at $80 \mathrm{~km}$ southeast of Paris, distant from the main traffic roads and partially protected by the large forest of Fontainebleau, a Biosphere Reserve since 1998. With the dominant winds direction being southwest (Fig. 1), all of the selected suburban cemeteries are only slightly influenced by air pollution from Paris. Nevertheless, even at $20 \mathrm{~km}$ from Paris and not under the direct influence of the pollution produced in this metropolis, Versailles remains a significant touristic and financial center and an intermediate level of pollution was expected in this area.

\section{Moss sampling and preparation}

All moss samples were collected during six consecutive days in December 2013. While mosses of different species were present in each cemetery (two to nine species), G. pulvinata (Hedwig) Smith was the only species abundantly present in all cemeteries. Pearson et al. (2000) showed that, in London, this species was indeed suitable for identifying different levels of exposures to metal depositions, and so, we decided to focus the sampling effort on this species for the purpose of this study. All the collected samples were exclusively epilithic mosses, that is bryophytic colonies developed on rocky substrates. In order to avoid risks of elemental transfers by water runoff, attention was paid that no overhanging tree canopy or surface was present above sampled moss cushions. As such, whenever 


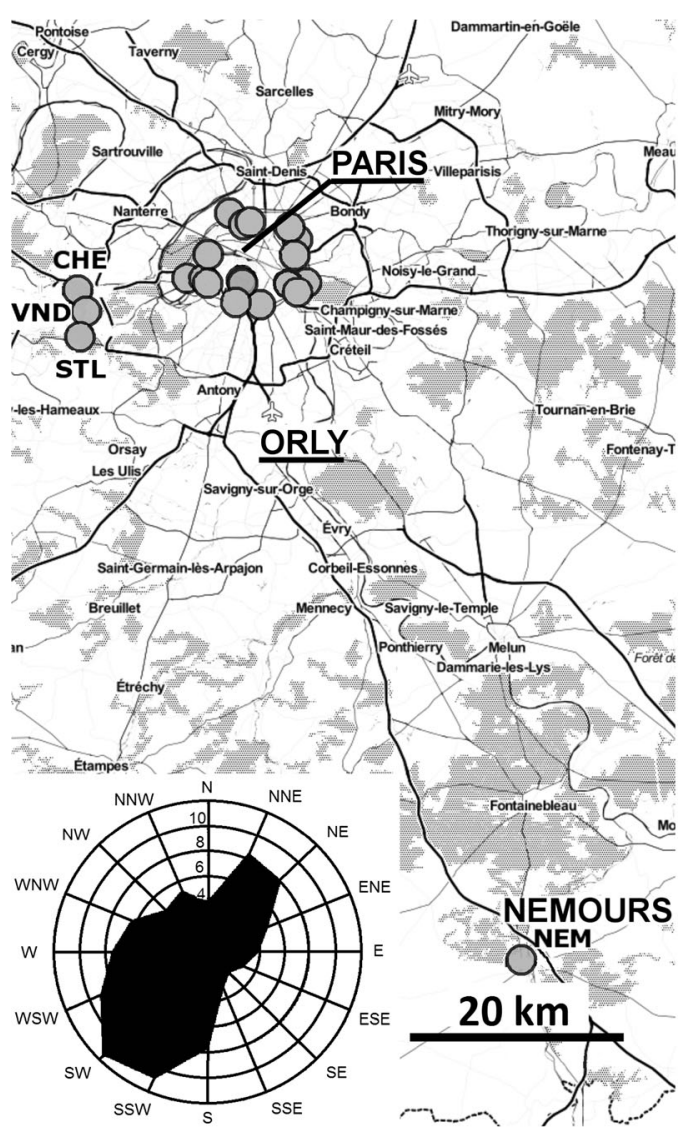

Fig. 1 Location of the sampled cemeteries. Cemeteries in the historical center of Paris (France) (city area surrounded by the Paris ring road with, in clockwise order from top (right) (BAT Batignolles, MON Montmartre, $S V$ St. Vincent, $L A V$ La Villette, $B E L$ Belleville, $P L$ Père-Lachaise, $S M S$ St. Mandé, BER Bercy, VAL Valmy, GEN Gentilly, MPP Petit Montparnasse, $M P G$ Grand Montparnasse, MR Montrouge, VAU

possible, the sampled tombs were far $(>50 \mathrm{~m})$ from nearest buildings and graveyard walls. Gravestones under or near trees, or in the shade of enclosure walls were also excluded. Finally, mosses directly under headstones, or cushions that could be under the influence of metallic objects (flower pots, religious objects, photograph frames, or iron letters) were also rejected.

Five tombs were chosen in each cemetery in order to homogenously cover the largest part of the cemetery area. After the GPS coordinates of each tomb were registered, entire moss cushions ( 1 per tomb), with a diameter between 3 and $5 \mathrm{~cm}$, were collected and immediately placed into sealed PE plastic bags. In six cemeteries, on one among the selected tombs, the diameter of moss cushions was smaller than $3 \mathrm{~cm}$ and we collected two moss cushions instead of one. In Batignolles cemetery (BAT), only four moss cushions showed the necessary properties. For all 21 cemeteries, the final sampling panel numbered 110 moss cushions.

The treatment of the moss samples before the process of measurement is a delicate step (Türkan et al. 1995; Markert et al. 1999; Fernández et al. 2007; Aboal et al. 2010, 2011). Mosses are not washed when information on the dust deposited on their leaves is investigated (or it is necessary to collect and analyze the washing water). However, when only metals inside moss tissues are of interest (as in the present study), mosses are washed using different liquids and techniques. Some authors wash the samples with tap, or deionized or double distilled or Millipore water (Thöni and Hertz 1992; Stryjewska et al. 1994; Türkan et al. 1995; Tsikritzis et al. 2002; Migaszewski et al. 2002). In these investigations, the washing time duration ranges from a few seconds to $10 \mathrm{~min}$. The use of water displaces ions from moss tissues to the rinse water and vice versa and a washing time of more than $30 \mathrm{~s}$ likely causes the loss of biomaterial and minerals (Sentenac and Grignon 1981; Wells and Brown 1990).

Taking this into account, the green part of each cushion corresponding to $3-5 \mathrm{~mm}$ of leaved stems was cut and gently washed for less than $30 \mathrm{~s}$ with ultrapure water (Millipore, USA). The washed material was then collected in Petri dishes and air dried during 5 days. The dried material was then ground (Retsch MM200 grinder, $24 \mathrm{~Hz}, 2 \min 30$ ) and the powder produced was transferred into $2.5-\mathrm{ml}$ sterile Eppendorf vials. 


\section{Determination and validation of element concentration by slurry-TXRF}

Moss slurry samples were prepared in 2.5-ml sterile Eppendorf vials, first by adding 4 to $8 \mathrm{mg}$ of dry moss powder, then adding $1 \mathrm{ml}$ of ultrapure (Millipore) water, and finally adding $20 \mu \mathrm{l}$ of Ga standard solution prepared at a concentration of $100 \mathrm{ppm}$. Slurries were homogenized using an electromagnetic vibrating vial shaker. One hundred microliters of slurry was pipetted from the well-homogenized slurry onto the TXRF quartz sample carrier, using sterilized metal-free Gilson $1000-\mu l$ pipette tips, immediately after shaking to avoid possible sedimentation.

To determine element concentrations, two TXRF analyses of moss slurries were carried out using a TX 2000 X-Ray Spectrometer manufactured by Ital-structures, equipped with a molybdenum/tungsten anode X-Ray tube, and operating with Mo $\mathrm{K} \alpha$ as excitation radiation. Quartz sample carriers were cleaned by soaking for $24 \mathrm{~h}$ in $10 \%$ analytic grade nitric acid followed by soaking for several hours in ultrapure water (Millipore) and then rinsed with ultrapure water and finally dried in a stream of clean nitrogen. Carriers were siliconized using in-house prepared solution of dimethyl-dimethoxysilane (DMDCS) 1 vol\% in ethanol. Sample carrier blanks were analyzed for contamination prior to sample deposition. Both carrier blanks and samples were excited for $3000 \mathrm{~s}$. Metal concentrations were determined by internal standardization, using a Ga standard solution. Si and other light elements such as $\mathrm{Na}$ or $\mathrm{Mg}$ were not determined since (i) the samples were placed on a quartz holder that contains $\mathrm{Si}$ and (ii) the energy of the fluorescence radiation for $\mathrm{Na}$ and $\mathrm{Mg}$ was too low to be detected by the instrument.

To validate the slurry-TXRF method, we compared element concentrations determined by the slurry method to those obtained by sample digestion. Digestion was done in Teflon containers (Savillex $60 \mathrm{ml}$ ), hermetically sealed after thoroughly cleaning according to Holy et al. (2009). Few milligrams of moss powder was weighed accurately and added into the containers. Three milliliters of ULTREX II ultrapure nitric acid $(63 \%)$ was added as well as $1 \mathrm{ml}$ of ultrapure water (Millipore). Finally, about $20 \mu \mathrm{l}$ of a Ga standard solution at $100 \mathrm{ppm}$ was pipetted into the same container and weighed using an analytical balance. Hermetically closed containers were ramped up to $135^{\circ} \mathrm{C}$ in an oven during $4 \mathrm{~h}$ and then kept at $135^{\circ} \mathrm{C}$ for $16 \mathrm{~h}$ for digestion. After cooling down, the containers were carefully opened and some tens of microliters of the digested samples were pipetted onto TXRF siliconized quartz carriers. Three subsamples from a given moss powder were digested simultaneously in three distinct digestion vessels. The amount of moss powder digested in each container was still in the 4-8-mg range, close to the mass used for the slurry method. A fourth container, containing only the nitric acid-water mix and the Ga standard, was used as a digestion blank, to check for eventual contamination. To evaluate the accuracy of the determined metal concentrations, we analyzed National Institute of Standards and Technology (NIST, USA) pine needle standard samples (i.e., SRM 1575a) by TXRF, considering both methods (slurry and digestion).

\section{Assessment of pollution levels by calculation of enrichment factors (EFs)}

To assess which elements principally contributed to atmospheric pollution in the Paris area, a first approach determined the relative enrichment factors (EFs) with respect to the cemetery of Nemours (NEM) considered as the background, less polluted site, out of the city and protected by the large forest of Fontainebleau. Taking Al as a commonly used normalization element (Gombert et al. 2004) and comparing the element ratios in a site of interest to the same element ratios in NEM, the background EFs were defined using the following equation:

$\mathrm{BEF}_{\text {element }}=[\mathrm{c}($ element $)$ sample / c (Al)sample $] /$ [c(element)background / c(Al)background].

As soil dust also plays an important role in moss accumulation, a common way to evaluate the soil-dust contribution is to compare element ratios in a site of interest, typically computed with respect to Al (Gombert et al. 2004), with the corresponding ratios in the upper continental crust. The average composition of the upper continental crust (Wedepohl 1995; Taylor and McLennan 1995) is often taken as a reference for the composition of soil dust and the corresponding crustal enrichment factors (CEFs) calculated as follows:

$\mathrm{CEF}_{\text {element }}=[\mathrm{c}($ element $)$ sample $/ \mathrm{c}(\mathrm{Al})$ sample $/$ c(element)crust / c(Al)crust].

The use of limited sites to calculate background concentrations of each element for EF calculation may be insufficient for obtaining a representative general reference on the subcontinental-scale (Reimann and Garret 2005). It is nevertheless appropriate for standardizing a set of data collected in a confined region when the aim is to identify eventual variations of values within this area. Moreover, a recent study in Canada (Cowden et al. 2015) suggests that while heavy metal concentrations may be variable between species of mosses, similar trends in the same area can be observed.

\section{Statistical analyses}

All statistical analyses were performed by using $\mathrm{R}$ software ( $\mathrm{R}$ Development Core Team 2014). The scope of the present survey was to use mosses as biomonitors of air quality and to associate a pollution score to each site rather than mapping single element concentrations - as concentrations of trace metal in biomonitors tissues may change with the measurement methodology. This may be done by computing a "multimetal contamination index" as a weighted average of element 
concentrations as reported by Thévenot et al. (2007) and Holy et al. (2009). However, when different elements are correlated (soil dust elements are usually correlated), a set of "multielement" scores can be computed by performing principal component analysis (PCA), attributing to each moss cushion the PCA component scores and averaging PCA scores for each site. These average scores then represent the contribution of a given pollution source to the sites corresponding to an element fingerprint stated by the PCA component loadings. The element fingerprint or component loadings represent the typical element ratios in the pollution source associated with the component. Furthermore, the standard deviation of the PCA scores at a given site represents the homogeneity of the site with respect to the given pollution source.

Since the large dynamic range of element concentrations (from less than 1 to more than 10,000 ppm) did not allow performing a PCA analysis on a rough element concentrationsample data matrix, we reduced and centered the data with respect to arithmetic standard deviation and arithmetic mean of the $\log$ concentrations before applying PCA. As suggested in Brumelis et al. (2000), we performed a Varimax rotation (Varimax function) of the principal components of the analysis in order to maximize the sum of the variances of the squared loadings.

To verify the log-normal distribution of the measured element concentrations, a set of normality tests were performed. After log-transforming the element concentration data, Shapiro-Wilk test of normality gave $p$ values $>0.05$ for all elements except As, Ca, Ce, Cl, P, S, Sr, and V. A Kolmogorov-Smirnov test (comparing the set of logtransformed element concentrations to a set of normally distributed random numbers having the same mean and standard deviation) confirmed the log normal distribution for all elements except $\mathrm{P}, \mathrm{Ce}, \mathrm{Cl}$, and As. Finally, a Wilcoxon test (two series of data compared two by two, chosen in the same way as for the Kolmogorov-Smirnov test) gave all $p$ values above 0.05 .

To clarify the site effect on pollutant distribution, cemeteries were classified into three groups: lowly, moderately, and highly polluted cemeteries based on both the ranking of their average PCA component score and estimated environmental condition (green space, number of trees, distance from roads, and exposition to main winds), nonparametric rank tests were performed on the element concentrations to prove the effectiveness of this classification, Wilcoxon test for groups of cemeteries taken two by two and Kruskal-Wallis for all groups together.

\section{Results}

\section{Slurry-TXRF method validation}

In Table 1, element concentration values and corresponding measurement errors (standard deviation of values) are compared for slurry-TXRF and digestion-TXRF methods for a pine needle standard reference material (SRM 1575a) and for a selected moss sample. In the case of pine needle samples, the results are also compared with certified values reported in Markert et al. (1994), which summarized the statements of 12 different authors. Results were obtained by analyzing three subsamples of the same slurry sample or three powder subsamples digested in separate vessels.

Pairwise agreements were found between slurry-TXRF, TXRF-digested, and certified values for the pine needle standard reference material, within error of measurements. In moss samples, agreement within errors was obtained for all elements except $\mathrm{Cl}, \mathrm{Pb}$, and $\mathrm{Ti}$. The relatively high errors are due to the intrinsic inhomogeneity of moss samples at the small quantities used for the analysis. Since sufficient agreement was obtained between digestion-TXRF and slurryTXRF concentration values, suggesting that sedimentation errors were avoided by our procedure to pipette slurries immediately after homogenization (as also suggested in De La Calle et al. 2013), we decided not to use surfactants. Results are also expressed in Fig. 2, where the spectra of digestion-TXRF and slurry-TXRF processes are represented, directly showing how element relative peak heights match closely in the two spectra.

\section{Trace element concentrations and enrichment factors}

When grouping together the 110 samples, the regional trace element concentrations in urban and suburban mosses decreased according to the following order $\mathrm{Ca}>\mathrm{Fe}>\mathrm{K}>\mathrm{S}>\mathrm{Al}>\mathrm{Cr}>\mathrm{P}>\mathrm{Cl}>\mathrm{Ti}>\mathrm{Zn}>\mathrm{Cu}>\mathrm{Mn}>\mathrm{Pb}>\mathrm{Sr}>\mathrm{Ce}>-$ $\mathrm{Ni}>\mathrm{Rb}>\mathrm{V}>\mathrm{Br}>$ As (Fig. 3a). All these elements are known to be associated to different natural or anthropogenic sources, which can sometimes interfere at regional scale.

To separate anthropogenic from natural soil dust contributions, we compared the enrichment factors (EFs) of urban and suburban moss samples computed with respect to $\mathrm{Al}$ taking the average composition of the upper continental crust as reference. Local variations of soil compositions can obviously occur, but these variations did not play a significant role in previous analysis involving French soils and mosses (Hernandez et al. 2003; Gombert et al. 2004; Reimann and Garret 2005; Reimann and de Caritat 2005; Reimann et al. 2005; Galuszka and Migaszewski 2011). When grouping together the 110 samples, the regional trace element crustal enrichment factors (CEFs) in mosses decreased according to the following order $\mathrm{Cr}>\mathrm{Br}>\mathrm{S}>\mathrm{Cu}>\mathrm{Pb}>\mathrm{As}>$ $\mathrm{Zn}>\mathrm{Ni}>\mathrm{Cl}>\mathrm{P}>\mathrm{Ca}>\mathrm{Ce}>\mathrm{V}>\mathrm{Fe}>\mathrm{K}>\mathrm{Rb}>\mathrm{Mn}>\mathrm{Sr}>\mathrm{Ti}>\mathrm{Al}=1$ (Fig. 3b). The nearer the CEFs values are to 1 (value assigned to $\mathrm{Al}$ ), the more the corresponding elements are likely to have soil dust as a source. Three groups stand out from these ordered CEF values: low ( $<10$ : Ti, Sr, Mn, Rb, K, Fe, and V), 
Table 1 Comparisons of concentrations and measurement errors (standard deviation) for the slurry-TXRF and digestion-

TXRF methods

\begin{tabular}{|c|c|c|c|c|c|c|}
\hline \multicolumn{4}{|c|}{ NIST 1575 pine-needle SRM } & \multicolumn{3}{|c|}{ Moss sample } \\
\hline & $\begin{array}{l}\text { Certified } \\
\quad \text { [Maerkert 1994] } \\
\quad(\mathrm{ppm})\end{array}$ & $\begin{array}{l}\text { Slurry-TXRF } \\
(\mathrm{ppm})\end{array}$ & $\begin{array}{l}\text { Digestion-TXRF } \\
\quad(\mathrm{ppm})\end{array}$ & & $\begin{array}{l}\text { Slurry-TXRF } \\
(\mathrm{ppm})\end{array}$ & $\begin{array}{l}\text { Digestion-TXRF } \\
\quad(\mathrm{ppm})\end{array}$ \\
\hline As & $0.21 \pm 0.02$ & $0.94 \pm 0.67$ & $0.12 \pm 0.21$ & $\mathrm{Al}$ & $2015 \pm 179$ & $2497 \pm 1230$ \\
\hline $\mathrm{Ba}$ & $7.2 \pm 0.8$ & $8.5 \pm 4$ & $12 \pm 3$ & As & $2.2 \pm 1.5$ & $3 \pm 1.6$ \\
\hline $\mathrm{Ca}$ & $4200 \pm 360$ & $4383 \pm 551$ & $4716 \pm 521$ & $\mathrm{Br}$ & $4 \pm 0.2$ & $3 \pm 1$ \\
\hline $\mathrm{Cr}$ & $2.6 \pm 0.2$ & $1.4 \pm 0.9$ & $2.1 \pm 1.5$ & $\mathrm{Ca}$ & $25,116 \pm 3245$ & $25,924 \pm 8455$ \\
\hline $\mathrm{Cu}$ & $3 \pm 0.4$ & $2.7 \pm 0.7$ & $6.1 \pm 3.1$ & $\mathrm{Ce}$ & $31 \pm 8$ & $14 \pm 23$ \\
\hline $\mathrm{Fe}$ & $185 \pm 26$ & $151 \pm 68$ & $194 \pm 35$ & $\mathrm{Cl}$ & $180 \pm 20$ & $23 \pm 39$ \\
\hline K & $3670 \pm 310$ & $3135 \pm 567$ & $3740 \pm 367$ & $\mathrm{Cr}$ & $510 \pm 21$ & $644 \pm 211$ \\
\hline $\mathrm{Mn}$ & $650 \pm 70$ & $568 \pm 68$ & $645 \pm 57$ & $\mathrm{Cu}$ & $77 \pm 6$ & $91 \pm 29$ \\
\hline $\mathrm{Ni}$ & $2.5 \pm 0.3$ & $2.7 \pm 0.7$ & $3.7 \pm 0.8$ & $\mathrm{Fe}$ & $6929 \pm 177$ & $7314 \pm 1153$ \\
\hline $\mathrm{Pb}$ & $10.7 \pm 0.5$ & $7.3 \pm 2.3$ & $10.4 \pm 2.7$ & $\mathrm{~K}$ & $6103 \pm 515$ & $5833 \pm 1659$ \\
\hline $\mathrm{Rb}$ & $11.7 \pm 1$ & $10.6 \pm 1.8$ & $11.7 \pm 1.1$ & $\mathrm{Mn}$ & $102 \pm 12$ & $102 \pm 24$ \\
\hline $\mathrm{S}$ & $1320 \pm 110$ & $938 \pm 447$ & $1723 \pm 338$ & $\mathrm{Ni}$ & $13 \pm 0.5$ & $18 \pm 5$ \\
\hline $\mathrm{Sr}$ & $5 \pm 0.4$ & $4.6 \pm 2.8$ & $4.95 \pm 0.5$ & $\mathrm{P}$ & $775 \pm 32$ & $822 \pm 125$ \\
\hline $\mathrm{V}$ & $0.39 \pm 0.07$ & $1.3 \pm 2.1$ & $0.63 \pm 0.73$ & $\mathrm{~Pb}$ & $24 \pm 2.3$ & $28 \pm 0.6$ \\
\hline \multirow[t]{6}{*}{$\mathrm{Zn}$} & $67 \pm 9$ & $54 \pm 14$ & $62.8 \pm 4.9$ & $\mathrm{Rb}$ & $18 \pm 1.8$ & $17 \pm 0.4$ \\
\hline & & & & $\mathrm{S}$ & $2191 \pm 300$ & $2659 \pm 730$ \\
\hline & & & & $\mathrm{Sr}$ & $48 \pm 6$ & $44 \pm 11$ \\
\hline & & & & $\mathrm{Ti}$ & $301 \pm 23$ & $205 \pm 18$ \\
\hline & & & & $\mathrm{V}$ & $9 \pm 2.6$ & $14 \pm 8$ \\
\hline & & & & $\mathrm{Zn}$ & $179 \pm 8$ & $205 \pm 6$ \\
\hline
\end{tabular}

medium (20-30: Ce, Ca, P, Cl, and Ni), and high (>100: $\mathrm{Cr}$, $\mathrm{Br}, \mathrm{S}, \mathrm{Cu}, \mathrm{Pb}, \mathrm{As}$, and $\mathrm{Zn}$ ) CEFs.

Finally, in order to identify the main contributors to atmospheric pollution in the Paris Region, we compared the EFs of urban and suburban moss samples computed with respect to $\mathrm{Al}$ taking the average composition of our background site (Nemours). When grouping together the 110 samples, the regional trace element background enrichment factors (BEFs) in mosses decreased according to the following order $\mathrm{Cu}>\mathrm{Ni}>\mathrm{Fe}>\mathrm{Ti}>\mathrm{Cr}>\mathrm{V}>\mathrm{Mn}>\mathrm{Ce}>\mathrm{Pb}>\mathrm{Al}=1>\mathrm{As}$
$>\mathrm{Br}>\mathrm{Sr}>\mathrm{K}>\mathrm{S}>\mathrm{Ca}>\mathrm{Zn}>\mathrm{Cl}>\mathrm{P}>\mathrm{Rb}$ (Fig. 3c). There are therefore two groups constituted of trace element concentrations in mosses that are lower or higher with respect to the background site. We observed particularly higher values for $\mathrm{Cu}$.

\section{Correlations between trace elements at a regional scale}

Correlations between trace elements can help to discern whether they share common natural or anthropogenic sources as well as providing a potential identification of the origin of the
Fig. 2 NIST SRM 1575 pine needle sample spectra from digestion-TXRF and slurryTXRF processes

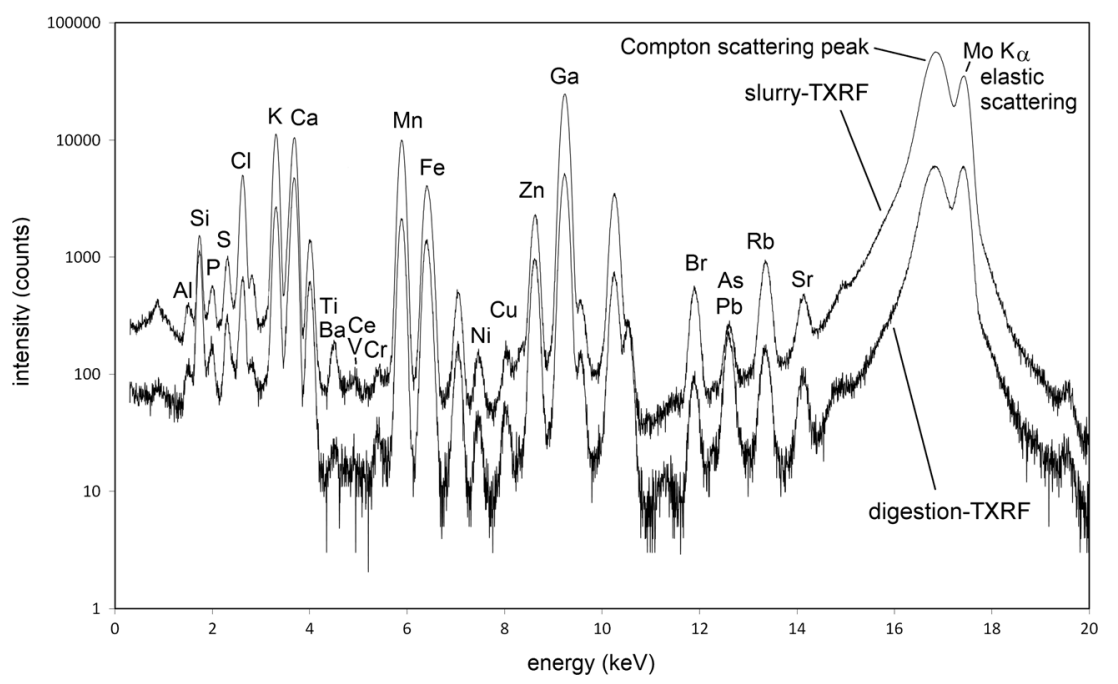




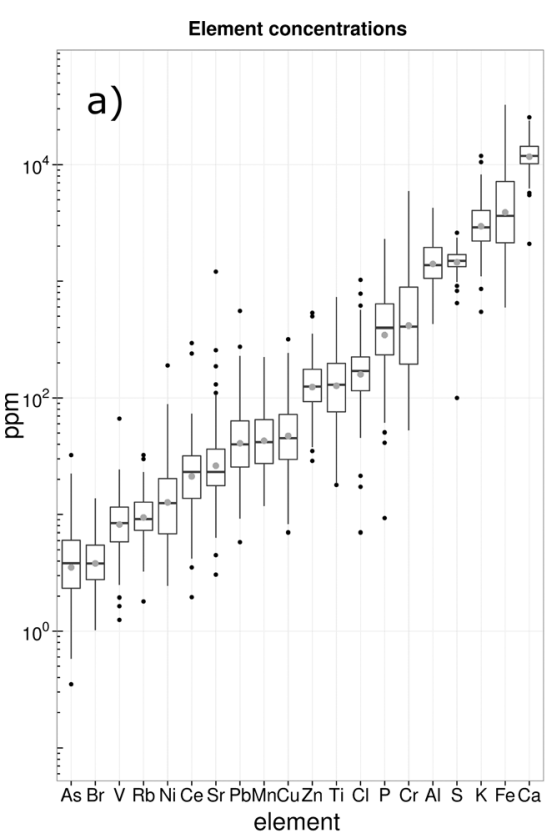

Fig. 3 Box and whisker plots of a) ordered elements concentration (ppm) in all moss samples, b) ordered crustal enrichment factors in all moss samples computed with respect to $\mathrm{Al}$ (left end) taking the average composition of the upper continental crust as reference, and c) ordered background enrichment factors in all moss samples taking $\mathrm{Al}$ (at center)

contamination. Varimax rotation applied on the PCA of all element concentrations showed that the first four rotated components (RC) explained $68 \%$ of total variance (Table 2). In order of decreasing explained variance, the first component $\mathrm{RC} 1$ had high loadings on $\mathrm{Fe}>\mathrm{Cr}>\mathrm{Ni}>\mathrm{Mn}>\mathrm{Al}>\mathrm{Cu}=\mathrm{Ti}>\mathrm{V}$ and explained nearly one third ( $28 \%$ ) of the variance. In particular, $\mathrm{Cr}, \mathrm{Ni}$, and $\mathrm{Mn}$ showed very high correlations $(0.94,0.90$, and 0.82 , respectively), while $\mathrm{Pb}$ was weakly correlated with the dominant elements of the component $\mathrm{RC} 1$. The third component RC3 had high loadings on $\mathrm{Br}>\mathrm{Zn}>\mathrm{Ti}>\mathrm{Ca}>\mathrm{Pb}>\mathrm{Cu}>\mathrm{V}$ and explained nearly one fifth (18\%) of the variance. The second component $\mathrm{RC} 2$ had high loadings on $\mathrm{K}>\mathrm{Rb}>\mathrm{Sr}$ and explained $13 \%$ of the variance. Finally, the fourth component RC4 had high loadings on $\mathrm{Cl}>\mathrm{S}$ and explained $9 \%$ of the variance.

\section{Site effect on pollution loads and site clustering according to their structural and spatial characteristics}

In order to clarify the weight of the site effect on pollutant distribution, cemeteries were ranged regarding to the increasing mean standardized values of element concentrations in mosses and arranged by PCA on the two most important components $(\mathrm{RC} 1$ and $\mathrm{RC} 3$, cumulative variance $=47 \%$ ), i.e., a gradient of cemetery sites ordered from less to highly polluted (Fig. 4). A large dispersion of values has been registered in the cemetery of Grenelle. This cemetery was the only one with a very large unpaved earthen recreation area that may have contributed a large amount of dust on tombs.
Background enrichment factors

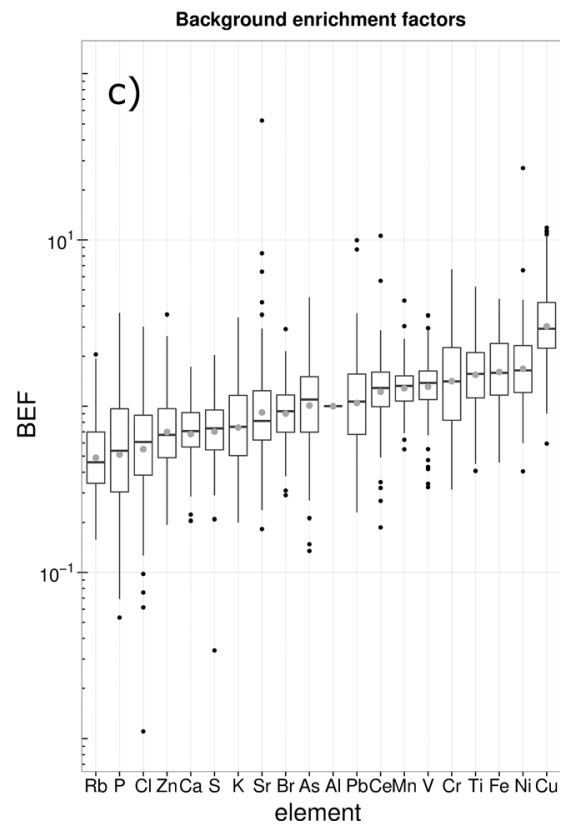

as normalization element and comparing the element ratios to those of the background site NEM. The range and 25th percentile/median/75th percentile box are shown for all plots. Extreme values are given and plotted as full diamonds

Differences were observed between the cemetery gradients of RC1 and RC3 due to the correlations between elements and components. However, a general trend could be observed when clustering sites. Since the group of less polluted cemeteries (which lie towards the bottom of the graphics) appeared to correspond to large and wooded cemeteries in the city center or to cemeteries surrounded by suburban gardens, farming, or less built-up environments, we decided to test the existence of three distinct groups of cemeteries following their geographical and environmental distribution.

The factors considered in grouping the cemeteries were total area (ha), amount of green space (i.e., lawns, hedges and shrub beds (ha)), number of planted trees, distance from the principal roads (the heavily frequented ring road of Paris and its main departing exit roads), and exposition to the prevailing winds from southwest, which are likely to sweep and deposit particles of traffic pollution on the cemeteries that lie immediately downwind of the ring road (Fig. 1). Even in cemeteries in the center of Paris, a high variability was observed since, e.g., total area ranged from 0.6 to 43.2 ha, or percentage of green space ranged from 0 to $15 \%$. Groups were:

1. Group 1, with expected relatively low polluted (LP) cemeteries: Montparnasse Grand (MPG), Montparnasse Petit (MPP), Nemours (NEM), Montmartre (MON), Père Lachaise (PL), and Chesnay (CHE)

2. Group 2, with expected moderately polluted (MP) cemeteries, i.e., cemeteries in the center of Paris or in the northern part of the city, and a large cemetery 
Table 2 Correlation coefficients of element concentrations with the first four components of the Varimax PCA rotation, listed in sequence of decreasing explained variance

\begin{tabular}{|c|c|c|c|c|}
\hline Elements & $\mathrm{RC} 1$ & $\mathrm{RC} 3$ & $\mathrm{RC} 2$ & $\mathrm{RC} 4$ \\
\hline SS-loadings & 5.64 & 3.69 & 2.59 & 1.72 \\
\hline Proportion-Var & 0.28 & 0.18 & 0.13 & 0.09 \\
\hline Cumulative-Var & 0.28 & 0.47 & 0.6 & 0.68 \\
\hline $\mathrm{Al}$ & 0.78 & 0.44 & 0.27 & -0.06 \\
\hline As & 0.14 & 0.26 & 0.12 & -0.25 \\
\hline $\mathrm{Br}$ & 0.36 & 0.77 & 0.02 & -0.12 \\
\hline $\mathrm{Ca}$ & 0.04 & 0.64 & 0.44 & 0.05 \\
\hline $\mathrm{Ce}$ & 0.4 & 0.28 & 0.32 & -0.01 \\
\hline $\mathrm{Cl}$ & 0.03 & -0.13 & -0.01 & 0.85 \\
\hline $\mathrm{Cr}$ & 0.94 & 0.01 & 0.02 & -0.07 \\
\hline $\mathrm{Cu}$ & 0.63 & 0.55 & 0.04 & 0.13 \\
\hline $\mathrm{Fe}$ & 0.96 & 0.2 & 0.03 & -0.06 \\
\hline K & -0.03 & -0.04 & 0.89 & 0.11 \\
\hline $\mathrm{Mn}$ & 0.82 & 0.41 & 0.27 & 0.03 \\
\hline $\mathrm{Ni}$ & 0.9 & 0.19 & -0.01 & -0.02 \\
\hline $\mathrm{P}$ & -0.1 & -0.36 & 0.38 & -0.01 \\
\hline $\mathrm{Pb}$ & 0.22 & 0.6 & -0.12 & -0.49 \\
\hline $\mathrm{Rb}$ & 0.2 & 0.11 & 0.8 & 0.13 \\
\hline $\mathrm{S}$ & 0.02 & 0.22 & 0.29 & 0.78 \\
\hline $\mathrm{Sr}$ & 0.26 & 0.15 & 0.62 & -0.02 \\
\hline $\mathrm{Ti}$ & 0.63 & 0.65 & 0.15 & -0.02 \\
\hline $\mathrm{V}$ & 0.62 & 0.5 & 0.23 & -0.08 \\
\hline $\mathrm{Zn}$ & 0.32 & 0.75 & -0.04 & 0.06 \\
\hline
\end{tabular}

The first three lines provide the total of sum of squared loadings and the proportional and cumulative variances, respectively. Correlation values $\geq 0.5$ are highlighted in bold

in Versailles that is in the middle of a residential part of the city: Batignolles (BAT), Belleville (BEL), La Villette (LAV), Saint-Vincent (SV), and Notre Dame de Versailles (VND)

3. Group 3, with expected highly polluted (HP) cemeteries, i.e., cemeteries bordering the ring road to the north, under the influence of the southwest prevailing winds, and a cemetery limiting Versailles toward the southwest and nearing main roads and railways: Auteuil (AUT), Bercy (BER), Gentilly (GEN), Grenelle (GRE), Montrouge (MR), Passy (PAS), Saint-Mandé (SMS), Valmy (VAL), Vaugirard (VAU), and Saint-Louis (STL)

Wilcoxon and Kruskal-Wallis tests on the element concentrations were used to identify the differences between these three groups (columns 1-2-3 and 4, respectively, in Table 3). They showed that the HP group was significantly more polluted than the LP group for all elements except $\mathrm{P}, \mathrm{Cl}$, and $\mathrm{K}$, and was significantly more polluted than the intermediate MP group for $\mathrm{Cu}, \mathrm{Ce}, \mathrm{Mn}, \mathrm{V}$, and $\mathrm{Rb}$. The MP group was more polluted than the LP group for 13 elements out of 20 except $\mathrm{P}$,
$\mathrm{K}, \mathrm{Cl}, \mathrm{S}, \mathrm{As}, \mathrm{Rb}$, and $\mathrm{Ca}$. When grouped all together, LP, MP, and HP were globally significantly different for almost the same 13 elements out of 20 than the MP vs. LP comparison, except for $\mathrm{Rb}$ instead of $\mathrm{Pb}$.

\section{Discussion}

\section{Is the slurry-TXRF method suited for mosses?}

The agreement between slurry-TXRF and digestion-TXRF methods for element concentrations against the NIST 1575 pine needle standard reference material is comparable to that found by Markert et al. (1994) for TXRF-digested moss samples (Table 1). This suggests that instrumental setup and sample preparation methods worked correctly and were not affected by major contamination (spectra in Fig. 2). It also shows that the slurry-TXRF method gives sufficiently accurate values. It is worth noting that for the selected moss sample in Table 1, the error is lower for slurry-TXRF than digestionTXRF, except for $\mathrm{Pb}, \mathrm{Rb}, \mathrm{Ti}$, and $\mathrm{Zn}$. This lower error for slurry-TXRF is probably because the results are obtained in three subsamples of the same slurry, while in the case of digestion-TXRF, we worked with three separate moss powder subsamples digested in three different vials. Since the mass of powder (ca. $4 \mathrm{mg}$ ) used to prepare a slurry sample was the same as that used for each of the three single digestion vessels, the powder digested separately in three distinct vessels revealed its inhomogeneity.

The relative smallness of the dispersion errors of slurryTXRF method when pipetting from the same slurry indicates that very reproducible results can be obtained when slurries are sufficiently homogeneous. In agreement with Meyer et al. (2012), we also observed that using surfactants (such as Triton $\mathrm{X}-100$ to obtain slightly more homogeneous dried sample spots on TXRF holders) significantly increased the background noise in TXRF spectra, making the quantification of low concentration elements more difficult. Surfactants were therefore not added to slurry samples. We also concluded that sedimentation errors were avoided by our procedure to pipette slurries immediately after homogenization as already proposed for instance by De La Calle et al. (2013).

However, for the selected moss sample, we observed some discrepancies among methods for a few elements: (i) $\mathrm{Pb}$ - the partial overlap of $\mathrm{Pb}$ and As peaks in TXRF spectra is a wellknown interference. The underestimation of $\mathrm{Pb}$ might be accompanied by an overestimation of As and vice versa, as observed for the pine needle sample. The above-reported moss powder inhomogeneity might greatly contribute to such differences; therefore, a finer grinding of moss samples would probably improve the results; (ii) Ti-titanium and barium form another spectral interference in TXRF so that their exact relative values can be difficult to determine. We analyzed 
$\mathrm{RC1}$

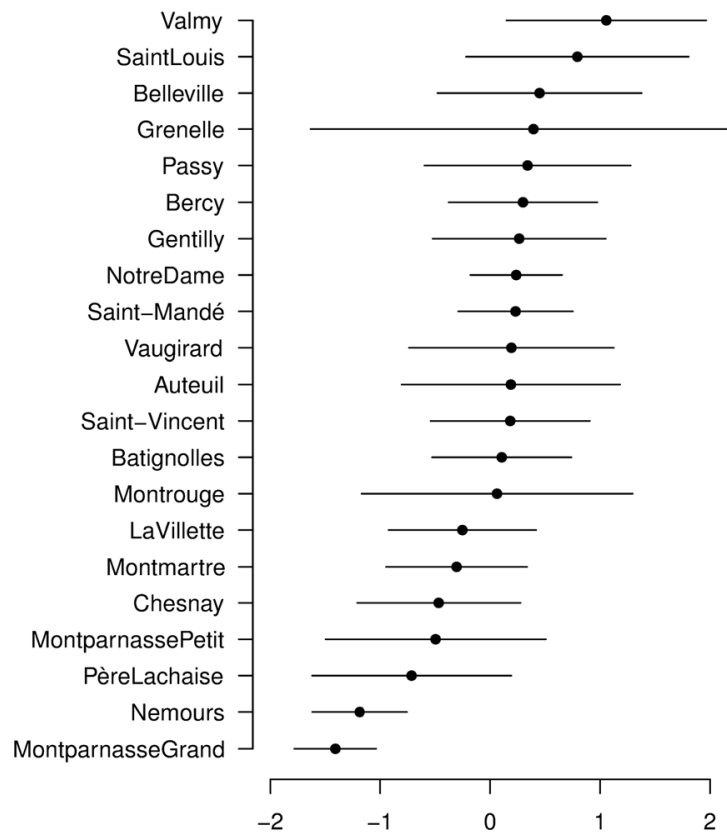

$\mathrm{RC3}$

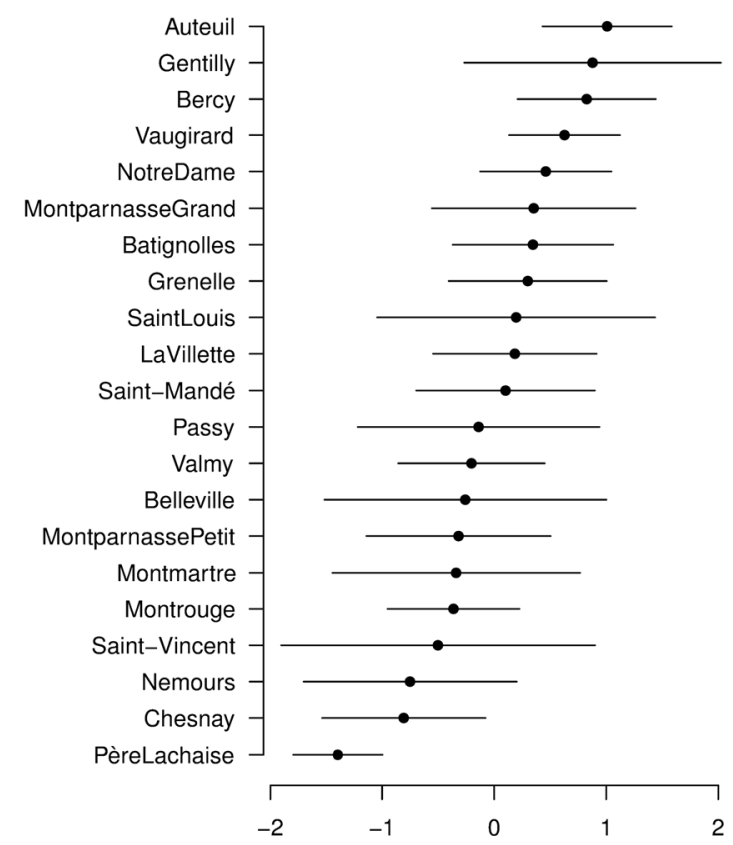

Fig. 4 Site effect on pollution loads. Scores (reduced and centered data, with respect to arithmetic standard deviation and arithmetic mean of the log concentrations of the elements in mosses) on the two most important Varimax rotated PCA components RC1 and RC3

Table 3 Wilcoxon (columns 1-2-3) and Kruskal-Wallis (column 4) tests on the concentrations of elements in moss from Parisian cemeteries grouped in highly polluted (HP), moderately polluted (MP), and lowly polluted (LP) clusters

\begin{tabular}{lllll}
\hline Elements & HP $>$ MP & HP $>$ LP & MP > LP & HP, MP, LP different \\
\hline $\mathrm{Al}$ & 0.126 & $\mathbf{0 . 0 0 0}$ & $\mathbf{0 . 0 0 0}$ & $\mathbf{0 . 0 0 0}$ \\
$\mathrm{As}$ & 0.233 & $\mathbf{0 . 0 1 2}$ & 0.072 & 0.068 \\
$\mathrm{Br}$ & 0.506 & $\mathbf{0 . 0 0 0}$ & $\mathbf{0 . 0 0 0}$ & $\mathbf{0 . 0 0 0}$ \\
$\mathrm{Ca}$ & 0.305 & $\mathbf{0 . 0 0 5}$ & 0.052 & 0.036 \\
$\mathrm{Ce}$ & $\mathbf{0 . 0 3 7}$ & $\mathbf{0 . 0 0 0}$ & $\mathbf{0 . 0 1 0}$ & $\mathbf{0 . 0 0 0}$ \\
$\mathrm{Cl}$ & 0.398 & 0.469 & 0.594 & 0.960 \\
$\mathrm{Cr}$ & 0.598 & $\mathbf{0 . 0 0 0}$ & $\mathbf{0 . 0 0 0}$ & $\mathbf{0 . 0 0 0}$ \\
$\mathrm{Cu}$ & $\mathbf{0 . 0 0 0}$ & $\mathbf{0 . 0 0 0}$ & $\mathbf{0 . 0 0 0}$ & $\mathbf{0 . 0 0 0}$ \\
$\mathrm{Fe}$ & 0.219 & $\mathbf{0 . 0 0 0}$ & $\mathbf{0 . 0 0 0}$ & $\mathbf{0 . 0 0 0}$ \\
$\mathrm{K}$ & 0.386 & 0.319 & 0.591 & 0.891 \\
$\mathrm{Mn}$ & $\mathbf{0 . 0 4 1}$ & $\mathbf{0 . 0 0 0}$ & $\mathbf{0 . 0 0 0}$ & $\mathbf{0 . 0 0 0}$ \\
$\mathrm{Ni}$ & 0.086 & $\mathbf{0 . 0 0 0}$ & $\mathbf{0 . 0 0 0}$ & $\mathbf{0 . 0 0 0}$ \\
$\mathrm{P}$ & 0.181 & 0.968 & 0.986 & 0.057 \\
$\mathrm{~Pb}$ & 0.492 & $\mathbf{0 . 0 2 0}$ & $\mathbf{0 . 0 3 7}$ & 0.085 \\
$\mathrm{Rb}$ & $\mathbf{0 . 0 2 3}$ & $\mathbf{0 . 0 0 0}$ & 0.071 & $\mathbf{0 . 0 0 1}$ \\
$\mathrm{S}$ & 0.175 & $\mathbf{0 . 0 3 2}$ & 0.283 & 0.174 \\
$\mathrm{Sr}$ & 0.156 & $\mathbf{0 . 0 0 0}$ & $\mathbf{0 . 0 0 6}$ & $\mathbf{0 . 0 0 0}$ \\
$\mathrm{Ti}$ & 0.052 & $\mathbf{0 . 0 0 0}$ & $\mathbf{0 . 0 0 0}$ & $\mathbf{0 . 0 0 0}$ \\
$\mathrm{V}$ & $\mathbf{0 . 0 3 0}$ & $\mathbf{0 . 0 0 0}$ & $\mathbf{0 . 0 0 0}$ & $\mathbf{0 . 0 0 0}$ \\
$\mathrm{Zn}$ & 0.077 & $\mathbf{0 . 0 0 0}$ & $\mathbf{0 . 0 0 2}$ & $\mathbf{0 . 0 0 0}$ \\
\hline
\end{tabular}

Four hypotheses were tested (headline of the table). $p$ values $<0.05$ are highlighted in bold barium in selected moss samples and found that it was always present in very low concentrations compared to Ti. As a consequence of this spectral interference with $\mathrm{Ti}$, we considered the $\mathrm{Ba}$ concentrations unreliable, and they were not presented in this paper; (iii) $\mathrm{Cl}$ and $\mathrm{Br}$-lower concentrations of $\mathrm{Cl}$ and $\mathrm{Br}$ (particularly $\mathrm{Cl}$ ) were observed in the digested samples. This is likely to be due to the evaporation of volatile $\mathrm{Cl}$ and $\mathrm{Br}$ compounds after the opening of digestion vessels (Naozuka et al. 2003). This underlines one of the advantages of the slurry-TXRF method, i.e., its capacity to reduce the risk of sample loss, which always occurs in digestion procedures when volatile species are generated during the process.

\section{Can G. pulvinata (Hedwig) smith be used as biomonitor for detecting air pollution?}

Despite its ubiquitous distribution, its ability to grow in hemispherical dense cushions as an adaptation to dry periods, and its tolerance to pollution, G. pulvinata has not yet been widely used in moss studies. Indeed, in over a hundred articles (published between 1972 and 2014) on the use of mosses for monitoring the atmospheric deposition of pollutants, only four include data of this species: Sawidis et al. (1999), Pearson et al. (2000), and Uğur et al. (2003, 2004). None of them are specifically dedicated to G. pulvinata. G. pulvinata was the only species present in all the Paris cemeteries and in a large number of colonies. Relatively easy to recognize, with colonies shaped in cushions that are convenient to sample, this 
species was also found to be practical to manipulate during every phase of the research and as well as being a good air pollution biomonitor, at least for the elements measured in this study (Al, As, Br, Ca, Ce, Cl, Cr, Cu, Fe, K, Mn, Ni, P, Pb, Rb, $\mathrm{S}$, Sr, Ti, and Zn).

\section{Is G. pulvinata a good biomonitor of regional and local sources of anthropogenic pollution?}

The assessment of trace element contamination at regional and subregional levels needs to clearly distinguish between natural or anthropogenic sources. This is challenging for several reasons: Elevated concentrations or deposition are not always the result of human activities; indeed, human activities can increase not only trace elements of anthropogenic but also those of natural origin, as soil dust generated by agricultural practices. First, plants concentrate essential elements for their growth and metabolism, such as the macro-nutrient elements $\mathrm{Ca}, \mathrm{K}, \mathrm{P}$, and $\mathrm{S}$ (i.e., elements with concentrations $>0.1 \%$ in plants) and the micro-nutrient elements $\mathrm{Fe}, \mathrm{Cu}, \mathrm{Mn}, \mathrm{Zn}, \mathrm{Ni}$, and $\mathrm{Cl}$. Second, natural sources include elements of marine origin such as $\mathrm{Cl}$ and $\mathrm{S}$ as well as soil dust elements. In the upper earth crust, these latter have concentrations that decrease as follows: $\mathrm{Si}>\mathrm{Al}>\mathrm{Fe}>\mathrm{Ca}>\mathrm{K}>\mathrm{Ti}$ (Wedepohl 1995; Taylor and McLennan 1995). Soil dust elements are likely to be important contributors to the metal content of mosses, especially if unwashed, as they constitute up to 5 to $20 \%$ of the mass of atmospheric particulate matter $<10 \mu \mathrm{m}$ $\left(\mathrm{PM}_{10}\right.$ — van der Gon et al. 2010), depending on regional conditions. Third and last, anthropogenic pollutants include $\mathrm{Pb}, \mathrm{V}$, $\mathrm{Zn}, \mathrm{Cr}, \mathrm{As}, \mathrm{Ni}, \mathrm{Ti}, \mathrm{Cu}, \mathrm{Mn}, \mathrm{S}$, or Br. Among these, $\mathrm{Cu}, \mathrm{Pb}$, and $\mathrm{Cr}$ are known as traffic markers (Stechmann and Dannecker 1990; Sternbeck et al. 2002), $\mathrm{Cu}$ and $\mathrm{Pb}$ from brake emissions, $\mathrm{Pb}$ and $\mathrm{Zn}$ from tyre wear emissions (Napier et al. 2008; Thorpe and Harrison 2008), and others like Ni and V are from heating emission related to fuel combustion. Ti, $\mathrm{V}, \mathrm{Cr}, \mathrm{Mn}, \mathrm{Ni}$, $\mathrm{Cu}, \mathrm{Zn}, \mathrm{Br}, \mathrm{Zr}$, and $\mathrm{Pb}$ were identified as anthropogenic sources in road dust (Sampson Atiemo et al. 2011); natural crustal, vehicular emissions, and corroded vehicular parts were identified as sources of these elements. The metal concentrations of $\mathrm{Cd}, \mathrm{Cr}, \mathrm{Cu}, \mathrm{Ni}, \mathrm{Pb}$, and $\mathrm{Zn}$ are greatly toxic and highly abundant in road traffic environments (Kumar Pal 2012). S is likely to arise from fuel and coal combustion plants (European Commission 2006). Lastly, volatile Br can be produced by incineration plants when they burn plastics containing $\mathrm{Br}$ as flame retardant (European Chemicals Bureau 2006).

On the regional level (Fig. 3b), the group of relatively low CEFs ( $<10$; Ti, Sr, Mn, Rb, K, Fe, and V) are likely to have local soils as probable source. On the other hand, the group of very high $\mathrm{CEFs}(>100 ; \mathrm{Cr}, \mathrm{Br}, \mathrm{S}, \mathrm{Cu}, \mathrm{Pb}, \mathrm{As}, \mathrm{Zn}$, and $\mathrm{Ni}$ ) contains elements mainly generated by anthropogenic sources, as traffic or organic matter combustion, including waste incineration (e.g., $\mathrm{Br}$ from flame retardants in plastics but also pesticides) or metal smelter industries. Finally, the elements within the group of medium CEFs (20-30) contain plant macro- and micro-nutrients such as not only $\mathrm{Ca}, \mathrm{P}, \mathrm{Ni}$, and $\mathrm{Cl}$ but also cerium. The concentration of cerium (major component of mischmetal alloy, also present in catalysts, pigments, flat-screen TVs, low-energy light bulbs, and floodlights) is probably due to industrial activities.

When comparing the overall regional level to our background site at Nemours (Fig. 3c), the elevated trace elements, besides $\mathrm{Ce}$, match the series of anthropogenic pollutants $(\mathrm{Pb}$, $\mathrm{V}, \mathrm{Zn}, \mathrm{Cr}, \mathrm{As}, \mathrm{Ni}, \mathrm{Cu}, \mathrm{Mn}$, and $\mathrm{S}$ ) with high values of the traffic marker $\mathrm{Cu}$. Not surprisingly in a Paris Region influenced by a subatlantic climate (Crippa et al. 2013), among the elements showing a lower background enrichment factor in Fig. 3c, we find $\mathrm{K}, \mathrm{S}, \mathrm{Ca}, \mathrm{Zn}, \mathrm{Cl}$ and $\mathrm{P}$, which could be derived not only from plants and soils but also from marine aerosols. It is to be noted that $\mathrm{Br}$ (flame retardant, gasoline additive, pesticide, medical, and veterinary use) and $\mathrm{Rb}$ (working fluid or getter (remover of trace gases) in vapor turbines, vacuum tubes, photocell, and glass industries) were relatively high in the Nemours samples. The elevated values of these elements are probably due to the proximity of a quartz and glass factory for the transport, electrical, and solar industries (Saint Gobain Quartz) and to the presence of intensive crop fields. CEFs are globally higher than BEFs calculated with respect to Nemours (Fig. 3), indicating that even in Nemours, the moss composition is not determined only by soil dust elements.

Finally, the correlations between trace elements using Varimax rotation on the PCA showed that the major component RC1 grouped high loadings on well-known soil dust elements as $\mathrm{Fe}$, Ti, and $\mathrm{Al}$, and classic anthropogenic pollutants (Stechmann and Dannecker 1990; Sternbeck et al. 2002) with particularly high correlations for $\mathrm{Cr}, \mathrm{Ni}$, and $\mathrm{Mn}(0.94$, $0.9,0.82$, respectively). This suggests that airborne soil dust acts as accumulator and transport medium also for anthropogenic pollutants. Soil dust represents a fraction of 5 to $20 \%$ of the mass of fine suspended particulates less than $10 \mu \mathrm{m}$ in diameter (PM10). Despite this apparent importance (van der Gon et al. 2010), PM10 sources are still poorly understood and not well represented in emission inventories. This is partly because some sources can be defined as natural ones (e.g., wind erosion), while others, such as resuspension, are not recognized as primary emission sources, but reemissions of already present particles.

In tunnel (Sternbeck et al. 2002) and more generally urban (Kulshrestha et al. 2009) dusts, the $\mathrm{Cu}-\mathrm{Pb}-\mathrm{V}$ association is known as to be typical of resuspended traffic dust. Specifically in the Ile-de-France Region, Jaecker-Voirol and Pelt (2000) showed that road traffic was a very significant source of $\mathrm{PM} 10$. The average $\mathrm{Pb} / \mathrm{Zn}$ concentration ratio in our mapped area is 3.73 with a standard deviation of 2.66 , which is relatively close to the one (2.8) previously observed in dry depositions in Paris by Garnaud et al. (1999). From 
1990, unleaded petrol progressively replaced the leaded petrol and $\mathrm{Pb}$ was definitively banned in France in January 2000. This fact may explain the weak correlation of $\mathrm{Pb}$ with the dominant soil dust elements of component RC1. However, a high loading on $\mathrm{Pb}$ can be found in $\mathrm{RC} 3$ together with other anthropogenic pollutants such as $\mathrm{Br}$ (liberated by incineration of plastics), $\mathrm{Zn}$, $\mathrm{Ti}$, and $\mathrm{Cu}$ (e. g. alloys, batteries, anti-corrosions, fuels, paints, electrical wires). Lastly, two other sources can be highlighted by $\mathrm{RC} 2$ aggregating high loadings on $\mathrm{K}>\mathrm{Rb}>\mathrm{Sr}$ as natural sources (e.g., plant debris), and RC4 with only high loadings of $\mathrm{Cl}$ and $\mathrm{S}$ and suggesting a marine origin.

\section{Can urban cemeteries be used as proxies of indicators and buffers of anthropogenic pollution?}

Available pollution maps in the Paris area (Airparif 2013) suggest an accumulation of PM10 and PM2.5 along major traffic routes. In Paris, away from streets, these maps suppose that pollution is homogeneously distributed over the city. Our results show more spatial variability even in densely urbanized areas, and that this variability seems to be linked to local landscape structure (e.g., cemetery size, vegetation cover, etc.) and exposure to emissions (e.g., point source pollutions, density of nearby traffic, etc.). Indeed, the largest and most wooded cemeteries in the center of Paris are as "clean" (or less polluted) as cemeteries far from Paris and near forests or farming environments such in Nemours or Chesnay. This is typically the case for the historical and tourist cemeteries of Père Lachaise and Montmartre, which together possess 5378 planted trees, i.e., $78 \%$ of all trees in the cemeteries within the Paris beltway. On the contrary, cemeteries that border the south part of the city beltway to their north (AUT, GRE, VAU, MR, GEN, VAL, BER, SMS) are more polluted than the others (the only elements not significant being from marine aerosols or plant debris $\mathrm{Cl}, \mathrm{P}, \mathrm{K}$ ). Leaching from the beltway, but above all, winds coming from the southwest of the Paris region are likely to pick up and then depose pollutants on mosses growing in these cemeteries. Interestingly, the expected moderately polluted cemeteries in the center of Paris or in the residential suburbs that had a lower percentage of green spaces are more polluted than "woodiest" cemeteries for part of the elements. Among the elements that do not confirm this trend are the plant macronutrients $(\mathrm{Ca}, \mathrm{K}, \mathrm{S}, \mathrm{P})$ and some of the elements $(\mathrm{Cl}, \mathrm{As}, \mathrm{Rb})$ associated with marine aerosol or anthropogenic sources. In fact, recent results have suggested that these nutrients should not be used for air pollution biomonitoring (Boquete et al. 2011), as their source is considered as natural and related to plant metabolism rather than anthropic sources.

\section{Conclusions}

Monitoring long-term global atmospheric pollution in a patchwork of urban and peri-urban areas that can rapidly evolve calls for systematic, integrative, and simple measures of trace element contamination. In this context, moss sampling in urban cemeteries provides a useful complement to measurement stations because contrary to other biomonitor sampling sites, cemeteries provide environments that are usually easy to access, regularly distributed and where moss cushions may remain undisturbed during long periods. Cemeteries also have different histories, structural and spatial characteristics that are linked to their local (proximity to traffic routes) and regional (main winds direction) environment. Both of which can help in deciphering the loads and sources of pollutants. Overall, our results also suggest that using TXRF measurements with slurry sample preparation is a suitable and fast technique to determine subtle variations in elemental concentrations and enrichments factors in mosses both at the regional and on fine site scales. This approach could therefore be useful for both local and regional PM10 risk assessments as it is particularly suited to being implemented alongside real-time measurements.

For the evaluation of the ecosystem services provided by urban and peri-urban cemeteries, intra-cemeteries transects of trace element concentrations in mosses from outside to inside cemeteries of differing characteristics should be done, when possible. An estimation of the age variability in mosses (and consequently the time they accumulate trace elements) under different environmental pressures (e.g., drought) should also be targeted. We sampled mosses of about the same size which may be important if age is linked to the size, as G. pulvinata functioning is closely related to the cushion size (Zotz et al. 2000). The use of mosses for biomonitoring is under development (Izquieta-Rojano et al. 2016), and the results of this work suggest that $G$. pulvinata is a good candidate for the survey of urbanized areas.

Acknowledgments This research was performed with material and instruments provided by each laboratory (IENI-CNR, Padova; iEES-Paris). Field work and sample transfer were carried out as completion of teaching Erasmus activities. The authors thank Marc Faudot (Head of Cemeteries Service for the City of Paris) for providing data on cemetery characteristics that supported our analysis and all the cemetery staff and keepers for the interesting discussions we had during fieldwork. The authors acknowledge the kind assistance of Michiko Ikezawa during the collection and preparation of moss samples. They thank two anonymous reviewers for their useful suggestions that greatly improved the quality of article. Emma RochelleNewall (Institut de Recherche pour le Développement - IRD) is also thanked for improving the English of the original manuscript.

\section{References}

Aboal JR, Fernández JA, Boquete T, Carballeira A (2010) Is it possible to estimate atmospheric deposition of heavy metals by analysis of terrestrial mosses? Sci Total Environ 408:6291-6297

Aboal JR, Pérez-Llamazares A, Carballeira A, Giordano S, Fernández JA (2011) Should moss samples used as biomonitors of atmospheric contamination be washed? Atmos Environ 45:6837-6840 
Airparif (2013). Air quality in the Paris Region 2013. http://www.airparif. asso.fr/_pdf/publications/bilan-2013-anglais.pdf. AIRPARIF - Air quality assessment network in the Paris region, Paris, France, 26 pp.

Ares A, Aboal JR, Carballeira A, Giordano S, Adamo P, Fernández JA (2012) Moss bag biomonitoring: a methodological review. Sci Total Environ 432:143-158

Barkàcs K, Varga A, Gàl-Solymos K, Záray G (1999) Direct determination of metal concentrations in freshwater algae by total reflection X-ray fluorescence spectrometry. J Anal At Spectrom 14:577-581

Boltersdorf SH, Pesch R, Werner W (2014) Comparative use of lichens, mosses and tree bark to evaluate nitrogen deposition in Germany. Environ Pollut 189:43-53

Bonizzoni L, Galli A, Gondola M, Martini M (2013) Comparison between XRF, TXRF, and PXRF analyses for provenance classification of archaeological bricks. X-Ray Spectrom 42:262-267

Boquete MT, Fernández JA, Aboal JR, Carballeira A (2011) Are terrestrial mosses good biomonitors of atmospheric deposition of Mn? Atmos Environ 45:2704-2710

Borgese L, Zacco A, Bontempi E, Colombi P, Bertuzzi R, Ferretti E, Tenini S, Depero LE (2009) Total reflection of X-ray fluorescence (TXRF): a mature technique for environmental chemical nanoscale metrology. Meas Sci Technol 20:1-7

Borgese L, Zacco A, Bontempi E, Pellegatta M, Vigna L, Patrini L, Riboldi L, Rubino FM, Depero LE (2010) Use of total reflection X-ray fluorescence (TXRF) for the evaluation of heavy metal poisoning due to the improper use of a traditional ayurvedic drug. J Pharm Biomed Anal 52:787-790

Borgese L, Salmistraro M, Gianoncelli A, Zacco A, Lucchini R, Zimmerman N, Pisani L, Siviero G, Depero LE, Bontempi E (2012) Airborne particulate matter (PM) filter analysis and modeling by total reflection X-ray fluorescence (TXRF) and X-ray standing wave (XSW). Talanta 89:99-104

Brumelis G, Lapin L, Nikodemus O, Tabors G (2000) Use of an artificial model of monitoring data to aid interpretation of principal component analysis. Environ Model Softw 15:755-763

Cantaluppi C, Natali M, Ceccotto F, Fasson A (2013) Multielemental analysis of powder samples by direct measurement with TXRF. X-Ray Spectrom 42:213-219

Carpi A, Weinstein LH, Ditz DW (1994) Bioaccumulation of mercury by sphagnum moss near a municipal solid waste incinerator. J. Air Waste Manag. Assoc. 44:669-672

Chakrabortty S, Paratkar GT (2006) Biomonitoring of trace element air pollution using mosses. Aerosol Air Qual Res 6:247-258

Chopra RN, Kumra PK (1988) Biology of Bryophytes. New Age International Publishers, Reprint 2005, 4835/24, Ansari Road, Daryaganj, New Dehli, 249-267

Correa Mazzoni A, Lanzer R, Bordin J, Schafer A, Wasum R (2012) Mosses as indicators of atmospheric metal deposition in an industrial area of southern Brazil. Acta Bot Bras 26:553-558

Cowden P, Liang T, Aherne J (2015) Mosses as bioindicators of air pollution along an urban-agricultural transect in the credit river watershed, southern Ontario, Canada. Ann Bot 5:63-70

Crippa M, El Haddad I, Slowik JG, DeCarlo PF, Mohr C, Heringa MF, Chirico R, Marchand N, Sciare J, Baltensperger U, Prévôt ASH (2013) Identification of marine and continental aerosol sources in Paris using high resolution aerosol mass spectrometry. J Geophys Res 118:1950-1963

De La Calle I, Costas M, Cabaleiro N, Lavilla I, Bendicho C (2012) Use of high-intensity sonication for pre-treatment of biological tissues prior to multielemental analysis by total reflection X-ray fluorescence spectrometry. Spectrochim Acta Part B 67:43-49

De La Calle I, Cabaleiro N, Romero V, Lavilla I, Bendicho C (2013) Sample pretreatment strategies for total reflection X-ray fluorescence analysis: a tutorial review. Spectrochim. Acta Part B 90:23-54

Esaka F, Watanabe K, Onodera T, Tagichi M, Magara M, Usuda S (2003) The use of Si carriers for aerosol particle collection and subsequent elemental analysis by total-reflection X-ray fluorescence spectrometry. Spectrochim. Acta. Part B 58:2145-2155

European Chemicals Bureau (2006) EU Risk Assessment Report (2006). 2, 2',6,6'-tetrabromo-4,4'-isopropylidenediphenol (tetrabromobisphenolA or TBBP-A). Part II - Human Health: 4th Priority List, Volume: 63, http://www.bsef.com/uploads/library/final_tbbpa_human_health_ report.pdf

European Commission (2006) Integrated Pollution Prevention and Control, Reference Document on Best Available Techniques for Large Combustion Plants, July 2006, executive summary VI, general information, p. 13: http://eippcb.jrc.ec.europa.eu/reference/BREF/lcp_ bref_0706.pdf

Fernández JA, Aboal JR, Real C, Carballeira A (2007) A new moss biomonitoring method for detecting sources of small scale pollution. Atmos Environ 41:2098-2110

Galuszka A, Migaszewski Z (2011) Geochemical background - an environmental perspective. Mineralogia 42:7-17

Garnaud S, Mouchel J-M, Chebbo G, Thévenot DR (1999) Heavy metal concentrations in dry and wet atmospheric deposits in Paris district: comparison with urban runoff. Sci Total Environ 235:235-245

Gerdol R, Marchesini R, Iacumin P, Brancaleoni L (2014) Monitoring temporal trends of air pollution in an urban area using mosses and lichens as biomonitors. Chemosphere 108:388-395

Giordano S, Adamo P, Sorbo S, Vingiani S (2005) Atmospheric trace metal pollution in the Naples urban area based on results from moss and lichen bags. Environ Pollut 136:431-442

Giordano S, Adamo P, Spagnuolo V, Tretiach M, Bargagli R (2013) Accumulation of airborne trace elements in mosses, lichens and synthetic materials exposed at urban monitoring stations: towards a harmonisation of the moss-bag technique. Chemosphere 90:292-299

Gombert S, Rausch de Traubenberg C, Losno R, Leblond S, Colin JL, Cossa D (2004) Biomonitoring of element deposition using mosses in the 2000 French survey: identifying sources and spatial trends. J Atmos Chem 49:479-502

Grodzinska K (1978) Mosses as bioindicators of heavy metal pollution in polish national parks. Water Air Soil Poll 9:83-97

Harmens H, Noris D, Aboal Viñas J, Alber R, Aleksiayenak Y, Ashmore M, Barandovski L, et al. (2008) Spatial and temporal trends in heavy metal accumulation in mosses in Europe (1990-2005); H. Harmens and D. Noris, Eds., Programme Coordination Centre for the ICP Vegetation, Centre for Ecology \& Hydrology, Natural Environment Research Council: Bangor

Harmens H, Norris DA, Cooper DM, Mills G, Steinnes E, Kubin E, Thöni L, Aboal JR, Alber R, Carballeira A, Coșkun M, Temmerman L, De Frolova M, González-Miqueo L, Jeran Z, Leblond S, Liiv S, Maňkovská B, Pesch R, Poikolainen J, Rühling Å, Santamaria JM, Simonèiè P, Schröder W, Suchara I, Yurukova L, Zechmeister HG (2011) Nitrogen concentrations in mosses indicate the spatial distribution of atmospheric nitrogen deposition in Europe. Environ. Poll. 159: 2852-2860

Harmens H, Foan L, Simon V, Mills G (2013) Terrestrial mosses as biomonitors of atmospheric POPs pollution: a review. Environ. Poll. 173:245-254

Harmens H, Schnyder E, Thöni L, Cooper DM, Mills G, Leblond S, Mohr K, Poikolainen J, Santamaria J, Skudnik M, Zechmeister HG, Lindroos A-J, Hanus-Illnar A (2014) Relationship between site-specific nitrogen concentrations in mosses and measured wet bulk atmospheric nitrogen deposition across Europe. Environ Pollut 194:50-59

Harmens H, Norris DA, Sharps K, Mills G, Alber R, Aleksiayenak Y, Blum O, Cucu-Man S-M, Dam M, De Temmerman L, Ene A, Fernández JA, Martinez-Abaigar J, Frontasyeva M, Godzik B, Jeran Z, Lazo P, Leblond S, Liiv S, Magnússon SH, Maňkovská B, Pihl Karlsson G, Piispanen J, Poikolainen J, Santamaria JM, Skudnik M, Spiric Z, Stafilov T, Steinnes E, Stihi C, Suchara I, Thöni L, Todoran R, Vurukova L, Zechmeister HG (2015) Heavy metal and nitrogen 
concentrations in mosses are declining across europe whilst some "hotspots" remain in 2010. Environ Pollut 200:93-104

Hernandez L, Probst A, Probst JL, Ulrich E (2003) Heavy metal distribution in some French forest soils: evidence for atmospheric contamination. Sci Total Environ 312:195-219

Holy M, Leblond S, Pesch R, Schröder W (2009) Assessing spatial patterns of metal bioaccumulation in French mosses by means of an exposure index. Environ. Sci. Pollut. R. 16:499-507

Injuk J, Van Grieken R (1995) Optimisation of total-reflection X-ray fluorescence for aerosol analysis. Spectrochim. Acta. Part B 50:1787-1803

Izquieta-Rojano S, Elustondo D, Ederra A, Lasheras E, Santamaría C, Santamaría JM (2016) Pleurochaete squarrosa (Brid.) Lindb. As an alternative moss species for biomonitoring surveys of heavy metal, nitrogen deposition and $\delta^{15} \mathrm{~N}$ signatures in a Mediterranean area. Ecol Indic 60:1221-1228

Jaecker-Voirol A, Pelt P (2000) PM10 emission inventory in Ile de France for transport and industrial sources: PM10 re-suspension, a key factor for air quality. Environ Model Softw 15:575-581

Klockenkaemper R (1997) Total-reflection X-ray fluorescence analysis. John Wiley \& Sons, New York, NY, USA 1997:67-77

Kulshrestha A, Satsangi PG, Masih J, Taneja A (2009) Metal concentration of PM2.5 and PM10 particles and seasonal variations in urban and rural environment of Agra, India. Sci. Total Environ 407:6196-6204

Kumar Pal S (2012) On heavy metal pollution from a suburban road network. PhD Thesis. Heriot Watt University, School of the BuiltEnvironment, Institute of Infrastructure and Environment, Edinburgh, UK, EH14 4AS, January 2012: 217p

Liu X-Y, Xiao H-Y, Liu C-Q, Xiao H-W, Wang Y-L (2009) Assessment of atmospheric sulfur with the epilithic moss Haplocladium microphyllum: evidences from tissue sulfur and $\delta^{34} \mathrm{~S}$ analysis. Environ Poll 157:2066-2071

Marguí E, Floor GH, Hidalgo M, Kregsamer P, Román-Ross G, Streli C, Queralt I (2010) Analytical possibilities of total reflection X-ray spectrometry (TXRF) for trace selenium determination in soils. Anal Chem 82:7744-7751

Markert B, Reus U, Herpin U (1994) The application of TXRF in instrumental multielement analysis of plants, demonstrated with species of moss. Sci Total Environ 152:213-220

Markert B, Wappelhorst O, Weckert V, Herpin U, Siewers U, Friese K, Breulmann G (1999) The use of bioindicators for monitoring the heavy-metal status of the environment. J Radioanal Nucl Chem 240: 425-429

Marks MAW, Wenzel T, Whitehouse MJ, Loose M, Zack T, Barth M, Worgard L, Krasz V, Eby GN, Stosnach H, Markl G (2012) The volatile inventory $(\mathrm{F}, \mathrm{Cl}, \mathrm{Br}, \mathrm{S}, \mathrm{C})$ of magmatic apatite: an integrated analytical approach. Chem Geol 291:241-255

Matschullat J, Scharnweber T, Garbe-Schönberg D, Walther A, Wirth V (1999) Epilithic lichen - atmospheric deposition monitors of trace elements and organohalogens? J Air Waste Manag Assoc 49:1201-1211

Maxhuni A, Lazo P, Kane S, Qarri F, Marku E, Harmens H (2016) First survey of atmospheric heavy metal deposition in Kosovo using moss biomonitoring. Environ. Sci. Pollut. R. 23:744-755

Meyer A, Grotefend S, Gross A, Wätzig H, Ott I (2012) Total reflection Xray fluorescence spectrometry as a tool for the quantification of gold and platinum metallodrugs: determination of recovery rates and precision in the ppb concentration range. J Pharm Biomed Anal 70:713-717

Migaszewski ZM, Galuszka A, Paslawswki P (2002) Polynuclear aromatic hydrocarbons, phenols and trace metals in selected soil profiles and plant bioindicators in the holy Cross Mountains, south-Central Poland. Environ Int 28:303-313

Montero A, Estévez J, Padilla R, López D (2009) Analytical performance of some methods for the determination of trace elements in lichens used as air quality assessment. J Radioanal Nucl Chem 281:569-575

Naozuka J, Mesquita Silva da Veiga MA, Oliveira PV, de Oliveira E (2003) Determination of chlorine, bromine and iodine in milk samples by ICPOES. J Anal At Spectrom 18:917-921
Napier F, Brian DA, Jefferies C (2008) A review of vehicle related metals and polycyclic aromatic hydrocarbons in the UK environment. Desalination 226:143-150

Pearson J, Wells DM, Seller KJ, Bennett A, Soares A, Woodall J, Ingrouille MJ (2000) Traffic exposure increases natural ${ }^{15} \mathrm{~N}$ and heavy metal concentrations in mosses. New Phytol 147:317-326

Pesch R, Schröder W, Schmidt G, Genssler L (2008) Monitoring nitrogen accumulation in mosses in central European forests. Environ Pollut 155:528-536

Pesh R, Schröder W (2006) Mosses as bioindicators for metal accumulation: statistical aggregation of measurement data to exposure indices. Ecol Indic 6:137-152

Poikolainen J, Kubin E, Piispanen J, Karhu J (2004) Atmospheric heavy metal deposition in Finland during 1985-2000 using mosses as bioindicators. Sci Total Environ 318:171-185

R Development Core Team (2014) R: A Language and Environment for Statistical Computing. Version 3.1.2 (2104-10-31). R Foundation for Statistical Computing, Vienna, Austria. ISBN 3-900051-07-0. URL http://www.R-project.org/

Reimann C, de Caritat P (2005) Distinguishing between natural and anthropogenic sources for element in the environment: regional geochemical surveys versus enrichment factors. Sci Total Environ 337:91-107

Reimann C, Garret RG (2005) Geochemical background - concept and reality. Sci Total Environ 350:12-27

Reimann C, Filzmoser P, Garret RG (2005) Background and threshold: critical comparison of methods of determination. Sci Total Environ 346:1-16

Rühling Á, Tyler G (1970) Sorption and retention of heavy metals in the woodland moss Hylocomium splendens. Oikos 21:92-97

Rühling Á, Rasmussen L, Mäkinen A, Pilegaard K, Steinnes E, Nihlgard B (1989) Surveying of the heavy-metal deposition in Europe using bryophytes as bioindicators: proposal for an international programme. Steering body of environmental monitoring in the Nordic countries. Nordic Council of Ministers, Copenhagen

Sabatini SE, Juárez AB, Eppis MR, Bianchi L, Luquet CM, Ríos-de Molina MC (2009) Oxidative stress and antioxidant defenses in two green microalgae exposed to copper. Ecotoxicol Environ Saf 72:1200-1206

Sampson Atiemo M, Francis Ofosu G, Kuranchie-Mensah H, Osei Tutu A, Linda Palm NDM, Arthur Blankson S (2011) Contamination assessment of heavy metals in road dust from selected roads in Accra, Ghana. Res J Environ Earth Sci 3:473-480

Sawidis T, Heinrich G, Chettri MK (1999) Cesium-137 monitoring using mosses from Macedonia, N. Greece. Water Air Soil Pollut 110:171-179

Schintu M, Cogoni A, Durante L, Cantaluppi C, Contu A (2005) Moss (Bryum radiculosum) as a bioindicator of trace metal deposition around an industrialised area in Sardinia (Italy). Chemosphere 60:610-618

Schmeling M, Klockow D (1997) Sample collection and preparation for analysis of airborne particulate matter by total reflection X-ray fluorescence spectrometry. Anal Chim Acta 1997(346):121-126

Schneider B (1989) The determination of atmospheric trace metal concentrations by collection of aerosol particles on sample holders for totalreflection X-ray fluorescence. Spectrochim Acta, Part B: Atomic Spectroscopy 44:519-523

Sentenac H, Grignon C (1981) A model for predicting ionic equilibrium concentrations in cell walls. Plant Physiol 68:415-419

Shacklette HT (1965) Bryophytes associated with mineral deposits and solutions in Alaska, US. Geol. Surv. Bull. 1198-G

Shaw AJ (1989) Metal tolerance in bryophytes. In: Heavy metal tolerance in plants: evolutionary aspects. CRC Press. Inc., Chapter 10:133-154

Shaw BJ, Semin DJ, Rider ME, Beebe MR (2012) Applicability of total reflection X-ray fluorescence (TXRF) as a screening platform for pharmaceutical inorganic impurity analysis. J Pharm Biomed Anal 63:151159

Stechmann H, Dannecker W (1990) Characterization and source analysis of vehicle-generated aerosols. J Aerosol Sci 21:287-290 
Steinnes E (1995) A critical evaluation of the use of naturally growing moss to monitor the deposition of atmospheric metals. Sci Total Environ 160: 243-249

Steinnes E, Rühling A, Lippo H, Mäkinen A (1997) Reference materials for large-scale metal deposition surveys. Accred Qual Assur 2:243-249

Sternbeck J, Sjödin A, Andréasson K (2002) Metal emissions from road traffic and the influence of resuspension - results from two tunnel studies. Atmos Environ 36:4735-4744

Stryjewska E, Krasnodebska B, Biala H, Teperek J, Rubels S (1994) Heavy metal determination in moss samples from the Kampinos National Park. Chem Anal 39:483-490

Sucharova J, Suchara I (2004) Bio-monitoring the atmospheric deposition of elements and their compounds using moss analysis in the Czech Republic. Results of the international bio-monitoring programme UNECE ICP-vegetation. Part I: elements required for the bio-monitoring programme 2000. Acta Pruhoniciana 77:1-135

Sutton MA, Pitcairn CER, Leith ID, van Dijk N, Tang YS, Skiba U, Smart S, Mitchell R, Wolseley P, James P, Purvis W, Fowler D (2004). Bioindicator and biomonitoring methods for assessing the effects of atmospheric nitrogen on statutory nature conservation sites. JNCC Report No. 356, Peterborough, UK

Taylor SR, McLennan SM (1995) The geochemical evolution of the continental crust. Rev Geophys 33:241-265

Thévenot DR, Moilleron R, Lestel L, Gromaire MC, Rocher V, Cambier P, Bonté P, Colin JL, de Pontevès C, Meybeck M (2007) Critical budget of metal sources and pathways in the Seine River basin (1994-2003) for $\mathrm{Cd}, \mathrm{Cr}, \mathrm{Cu}, \mathrm{Hg}, \mathrm{Ni}, \mathrm{Pb}$ and $\mathrm{Zn}$. Sci Total Environ 375:180-203

Thöni L, Hertz L (1992) Applicability of the moss Hypnum cupressiforme for bio-monitoring of heavy metals: 1 . An investigation of the site requirements. In: Merian E, Haerdi W (eds) Metal compounds in environment and life. Interrelation between chemistry and biology. Science and Technology Letters, Northwood, pp. 137-151

Thorpe A, Harrison RM (2008) Sources and properties of non-exhaust particulate matter from road traffic: a review. Sci Total Environ 400:270-282

Tsikritzis LI, Ganatsios SS, Duliu OG, Sawidis TD (2002) Heavy metals distribution in some lichens, mosses and trees in the vicinity of lignite power plants from western Macedonia, Greece. J Trace Microprobe T 20:1-17

Türkan I, Henden E, Ümmühan C, Kivilcim S (1995) Comparison of moss and bark samples as biomonitors of heavy metals in a highly industrialized area in Izmir, Turkey. Sci Total Environ 166:61-67

Tyler G (1970). Moss analyses: a method of surveying heavy metal deposition. In: M. Englund and W. T. Berry. Eds. Proceedings of the Second International Clean Air Congress, Academic Press New York, USA, pp. 129-132

Uğur A, Özden B, Saç MM, Yener G (2003) Biomonitoring of ${ }^{210}$ Po and ${ }^{210} \mathrm{~Pb}$ using lichens and mosses around a uraniferous coal-fired power plant in western Turkey. Atm Environ 37:2237-2245
Uğur A, Özden B, Saç MM, Yener G, Altmbaș Ü, Kurucu Y, Bolca M (2004) Lichens and mosses for correlation between trace elements and ${ }^{210} \mathrm{Po}$ in the areas near coal-fired power plant at Yatağan, Turkey. J Radioanal Nucl Chem 259:87-92

Van der Gon DH, Jozwicka M, Hendriks E, Gondwe M, Schaap M (2010) Mineral Dust as a component of Particulate Matters. Publication of the Netherlands Research Program on Particulate Matter Report 500099003, ISSN: 1875-2322 (print) ISSN: 1875-2314 (http://www.pbl. nl/en/publications/2010/Mineral-Dust-component-particulate-matter)

Varga I, Rierpl E, Tusai A (1999) Comparison of slurry preparation and microwave digestion of freshwater algae for multi-element analysis by total reflection X-ray fluorescence spectrometry. J Anal At Spectrom 14:881-883

Viet HN, Frontasyeva MV, Thu TMT, Gilbert D, Bernard N (2010) Atmospheric heavy metal deposition in northern Vietnam: Hanoi and Thainguyen case study using the moss biomonitoring technique, INAA and AAS. Environ Sci Pollut R 17:1045-1052

Wedepohl KH (1995) The composition of the continental crust. Geochim Cosmochim Acta 59:1217-1232

Wellenreuther G, Fittschen UEA, Achard MES, Faust A, Kreplin X, MeyerKlaucke W (2008) Optimizing total reflection X-ray fluorescence for direct trace element quantification in proteins I: influence of sample homogeneity and reflector type. Spectrochim Acta, Part B 63:1461-1468

Wells JM, Brown DH (1990) Ionic control of intracellular and extracellular Cd uptake by the moss Rhytidiadelphus squarrosus (Hedw.). Warnst New Phytol 116:541-553

Woelfl S, Mages M, Encina F, Bravo F (2006) Trace metals in microcrustaceans and Brazilian waterweed from a contaminated Chilean wetland using total reflection X-ray fluorescence spectrometry. Microchim Acta 154:261-268

Zarazúa-Ortega G, Poblano-Bata J, Tejeda-Vega S, Ávila-Pérez P, ZepedaGómez C, Ortiz-Oliveros H, Macedo-Miranda G (2013) Assessment of spatial variability of heavy metals in metropolitan zone of Toluca Valley, Mexico, using the biomonitoring technique in mosses and TXRF analysis. Sci. World J. 2013, Article ID 426492, 7 pp.

Zechmeister H (1994) Biomonitornig der Schwermetalldeposition mittels Moosen on Österreich. Monografien des Umweltbundesamtes, Wien, B 94:1-147

Zechmeister HG, Grodzinska K, Szarek-Lukaszewska G (2003) Bryophytes. In: Markert BA, Breure AM, Zechmeister H (eds) Bioindicators \& biomonitors - principles, concepts and applications. Elsevier, Amsterdam, pp. 329-375

Zotz GA, Schweikert W, Jetz H, Westerman H (2000) Water relations and carbon gain are closely related to cushion size in the moss Grimmia pulvinata. New Phytol 148:59-67 